\title{
Metromedia, Inc. v. City of San Diego: Constitutionality of Billboard Regulation
}

As concern for environmental quality has grown more widespread in recent years, governments at all levels have acted to protect the environment through regulation. While the federal government has taken well-known and important steps to combat probleins such as air and water pollution, state and local governments have used their police powers for such purposes as improving the appearance of the community. ${ }^{1}$ One of the most common types of regulation aimed at improving the visual environment is the zoning ordinance restricting the use of outdoor signs and billboards. Such zoning regulations banned most of the billboards in over one hundred California cities and towns, and in three entire states. ${ }^{2}$

Although many of these ordinances were enacted in the current wave of environmental legislation, billboard and sign regulation is not new. ${ }^{3}$ People have long complained about the unsightliness of billboards, ${ }^{4}$ and, in accordance with such sentiments, legislatures have froin time to time tried to regulate or remove thein. Several early atteinpts at billboard regulation are recorded in the case law. A 1903

1. Statements of purpose in many zoning ordinances recite aesthetic considerations such as those listed in San Diego's billboard ordinance: "to preserve and improve the appearance of the City as a place in which to live and work . . . " San Diego, Cal., Ordinance 10795 (New Series) (Marcl 14, 1972), quoted in Metromedia, Inc. v. City of San Diego, 26 Cal. 3d 848, 858 n.6, 610 P.2d 407, 411 n.6, 164 Cal. Rptr. 510, 514 n.6 (1980). See, e.g., Ladue, Mo., Ordinance 131, as amended by Ordinance 281, quoted in Stoyanoff v. Berkeley, 458 S.W.2d 305, 306-07 (Mo. 1970) ("that appropriate standards of beauty and conformity be fostered and encouraged").

2. Metromedia, Inc. v. City of San Diego, 26 Cal. 3d 848, 869, 610 P.2d 407, 419, 164 Cal. Rptr. 510, 522, (Tobriner, J.) prob. juris. noted, 101 S. Ct. 265 (1980). See HawaII Rev. Stat. $\$ \S 445-111$ to -121 (1976); ME. Rev. Stat. AnN. tit. 23, \$§ 1901-1925 (1980); VT. STat. ANN. tit. $10, \$ \S 481-505$ (1973).

3. See Comment, Architectural Controls: Aesthetic Regulation of Urban Environment, 6 URB. LAW. 622, 630-32 (1974) (discussing the imfluence of the environinental movement on zoning for aesthetic purposes).

4. Ogden Nasl's sentiments on the subject are well known:

I think that I shall never see

A billboard lovely as a tree.

Perliaps unless the billboards fall,

I'll never see a tree at all.

O. Nash, Song of the Open Road, in The FACE Is Familiar 21 (1941). F. Scott Fitzgerald was only shightly more subtle. In The Great Gatsby, the dommant feature in the ugly, desolate "valley of asles" is a grotesque billboard featuring the eyes of T.J. Eckleburg. F.S. FITzGERALD, ThE Great GatsBy 23 (1925). 
New York case dealt with the validity of a sign ordinance, ${ }^{5}$ while cases involving sign regulations were decided by the courts of New Jersey, Massachusetts, and Pennsylvania in 1905.6 A 1909 California case involved an East San Jose billboard ordinance that was similar in effect to many modern ordimances. ${ }^{7}$ These early decisions, which tend to strike down the restrictions in question, demonstrate that legislative regulation of signs has a long, if not always successful, history. ${ }^{8}$

Recent cases mvolving challenges to the validity of sign ordinances have posed some new issues. Two types of challenges appear frequently im these cases. One is the clann that enactment of the ordinance in question was an abuse of the police power, because sign prohibitions do not promote public health, safety, morals, or general welfare in the traditional sense. ${ }^{9}$ This issue has always been present in this type of case, but the problem has been seen in a new light with the increasing acceptance of the idea that the police power may be exercised solely for aesthetic purposes. ${ }^{10}$ In addition to this new view of the old police power issue, Supreme Court decisions in the last decade have given rise to another, completely new problem. Reversing its previous position, the Supreme Court has now indicated that the first amendment protects "commercial speecll" to some extent. ${ }^{11}$ Thus, cliallengers now clain that billboard prohibitions violate their rights to free speech.

In Metromedia, Inc. v. City of San Diego, ${ }^{12}$ the California Supreme Court considered both of these problems. The court resolved both in favor of the validity of San Diego's sign ordinance, holding that the police power may be exercised for solely aestletic purposes, and that San Diego's ban of off-site ${ }^{13}$ signs and billboards does not violate first amendment guarantees. ${ }^{14}$

5. People v. Green, 85 A.D. 400,83 N.Y.S. 460 (1903).

6. City of Passaic v. Paterson Bill Posting, Advertising \& Sign Painting Co., 72 N.J.L. 285, 62 A. 267 (1905); Cominonwealth v. Boston Advertising Co., I88 Mass. 348, 74 N.E. 601 (1905); Bryan v. City of Chester, $212 \mathrm{~Pa} .259,61$ A. 894 (1905).

7. Varney \& Green v. Willians, 155 Cal. 318, 100 P. 867 (1909).

8. For a brief summary of sign regulation cases in this century, see Cunningham, Billboard Control Under the Highway Beaulification Act of 1965, 71 Mich. L. REv. 1295, 1346-50 (1973).

9. The police power may be exercised only to promote the public health, safety, morals, or general welfare. Associated Hoine Builders of the Greater Eastbay, lnc. v. City of Livermore, 18 Cal. 3d 582, 604, 557 P.2d 473, 485, I35 Cal. Rptr. 4I, 53 (1976); Miller v. Board of Pub. Works, 195 Cal. 477, 490, 234 P. 381, 385 (1925).

10. See notes 36-38 and accompanying text infra. Compare Varney \& Green v. Williauns, I55 Cal. 318, 100 P. 867 (1909) (sign ban for aesthetic purposes abuses the police power) with Metromedia, Inc. v. City of San Diego, 26 Cal. 3d 848, 610 P.2d 407, 164 Cal. Rptr. 510 (1980) (overruling Vamey \& Green).

11. Compare Valentine v. Chrestensen, 316 U.S. 52 (1942) (coinınercial spcech unprotccted) with Virginia State Bd. of Pharmacy v. Virginia Consumer Council, 425 U.S. 748 (1976) (contra).

12. 26 Cal. 3d 848, 610 P.2d 407, 164 Cal. Rptr. 510, prob. juris. noted, 101 S. Ct. 265 (1980).

13. For the definition of off-site signs, see note 15 infra.

14. This decision was partly overruled by the legislature. CAL. Bus. \& Prof. CODE § 5412.5 
This Note first reviews the facts of the case and the opinions rendered by the California Supreme Court in Metromedia. It then argues that the court was correct in holding that the ordmance was a proper exercise of the pohice power, both because the ordinance is reasonably related to promoting traffic safety and because improving community aesthetics is a legitimate government purpose. The third part of the Note considers the first amendment issues, and finds that the court's analysis is deficient because it fails to give adequate attention to the ordimance's apphication to noncommercial speech. The Note argues that although the ordinance is constitutional as apphed to commercial speech, it is not constitutional as apphed to noncommercial speech, and therefore should have been held unconstitutional on its face.

The CAse

In 1972, the San Diego City Council enacted an ordinance that prohibits all off-site "outdoor advertising display signs." 15 The ordinance requires removal of existing signs after an anortization period ranging from ninety days to four years, depending on the location and depreciated value of the sign. ${ }^{16}$ The ordinance contains several exceptions, one of which permits "temporary political campaign signs . . . which are erected or inaintained for no longer than 90 days and which are reinoved within 10 days after the election to which they pertam.."17 Plaintiffs, who owned a substantial number of billboards affected by the ordinance, sued to enjoin its enforcenent, challenging its constitutionahity. The trial court granted the plaintiffs' notion for summary judgment, finding the ordinance invalid as an unreasonable exercise of police power and an abridgeinent of the first amendment right to freedoin of speech. The California Supreme Court reversed, upholding the ordinance agaimst both challenges.

(West Supp. 1981). The statute puts a moratorium on removal of outdoor advertising displays in existence on November 8, 1978, except when removal is necessary under the federal Highway Beautification Act of 1965, 23 U.S.C. $\$ 131$ (1976). See note 24 infra. The moratorium expires January 1, 1982).

15. San Diego, Cal., Ordinance 10795 (New Series) (March 14, 1972). Off-site signs are those that do not identify a use, facility, or service located on the premises or a product that is produced, sold, or manufactured on the premises. Id.

16. Id. But see note 14 infra.

17. San Diego, Cal., Ordinance 12189 (New Series) (Oct. 19, 1977). Other exceptions include: signs maintained in the discharge of a governmental function; bench advertising signs; commemorative plaques; religious symbols, holiday decorations, etc.; signs located within shopping malls not visible from any point on the boundary of the premises; signs designating premises for sale, rent, or lease; public service signs depicting time, temperature, or news; signs on vehicles conforming to city regulations; and temporary off-premises subdivision directional signs. 26 Cal. 3d at 856 n.1, 610 P.2d at 410 n.l, 164 Cal. Rptr. at 513 n.l. 
Justice Tobriner, writing for a four-member majority of the court, ${ }^{18}$ first confronted the issue of whether the ordinance represented a valid use of the police power, that is, whether it had a real or substantial relation to the public health, safety, morals, or general welfare. $\mathrm{He}$ found that the ordinance, as a natter of law, reasonably related to the goal of traffic safety. ${ }^{19}$ Tobriner further stated that even if the purpose of the ordinance was not to promote traffic safety but to improve the appearance of the community, the ordinance was still a legitinate exercise of the police power. ${ }^{20}$ The court held that beauty for its own sake is a proper community objective under modern conceptions of the police power. In so holding, the court overruled Varney \& Green $v$. Williams, ${ }^{21}$ which held that aesthetic considerations alone will not justify exercise of the police power. Tobriner described Varney \& Green as "unworkable" and "discordant with modern thouglt." Tobriner also rejected any distimction between an ordinance that merely "regulates" and one that "prohibits," finding that a community may completely prohibit a business even if it has not been found to be a public nuisance.

Justice Tobriner then moved on to consider the first ainendment question. He found that the United States Supreme Court had already resolved the federaI constitutionaI challenges in Suffolk Outdoor Advertising Co. v. Hulse. ${ }^{22}$ In that case, the Supreme Court dismissed, for lack of a substantial federal question, an appeal from the New York Court of Appeals decision uphoIding a similar ordinance. Tobriner treated the dismissal as a holding on the merits. Justice Tobrmer then considered the free speech issue under the California Constitution, ${ }^{23}$ relying heavily, however, on federal cases. Analyzing the issue almost exclusively in terns of commerciaI speech, the court held that the San Diego ordinance was a permissible time, place, and manner regulation because it was content-neutral, it served a significant government interest, and alternative methods of speech were available. ${ }^{24}$

18. Justices Richardson and Newman concurred in the judgment, although each wrote a separate concurring opinion expressing doubts about the majority position.

19. $26 \mathrm{Cal} .3 \mathrm{~d}$ at $858-59,610$ P.2d at 412,164 Cal. Rptr. at 515.

20. Id. at $860,610 \mathrm{P} .2 \mathrm{~d}$ at $412,164 \mathrm{Cal}$. Rptr. at 515 .

21. 155 Cal. 318, 100 P. 867 (1909).

22. 43 N.Y.2d 483, 373 N.E.2d 263, 402 N.Y.S.2d 368 (1977), appeal dismissed, 439 U.S. 808 (1978).

23. The California free speech guarantee says: "Every person may freely speak, write and publish his or lier sentiments on all subjects, being responsible for the abuse of this right. A law may not restraim or abridge liberty of speech or press." CAL. Const. Art. 1, \& 2(a) (West Supp. 1981).

24. The court went on to hold that the San Diego ordinance was partly preempted by the California Outdoor Advertising Act, CAL. Bus. \& Prof. CODE $\$ \S 5200-5486$ (West 1974), which is intended to comply with the requirements of the federal Highway Beautification Act of 1965, 23 U.S.C. $\S 131$ (1976). These acts preempted the San Diego statute only in that they require com- 
Justice Clark, the only dissenter, found that the ordinance violates the first amendment. ${ }^{25}$ Justice Clark did not treat the problein as one of commercial speech, pointing out that the ordinance could also ban signs and billboards containing political and social information. $\mathrm{He}$ argued that billboards deserve the same degree of first ainendment protection as other methods of speech, and that they could not be banned solely for obtrusiveness. Justice Clark found that the first ainendment interests involved outweighed the state's interests, and that these first amendment interests were even more important due to the absence of adequate alternative inethods of communication.

II

\section{The Police Power Issues}

The Califorma Suprenie Court first dealt with whether the San Diego ordinance was a vahid exercise of the police power. ${ }^{26}$ In reviewing an exercise of the police power, Califorma courts require that the regulation reasonably relate to a legitimate governmental purpose, ${ }^{27}$ and that the means employed not be arbitrary, unreasonable, oppressive, or discriminatory. ${ }^{28}$ The language of the San Diego ordinance indicates that it was enacted to serve two government purposes: to promote traffic safety and to inprove community aesthetics. ${ }^{29}$ The plaintiffs sought to sliow that neither sufficed, alleging that the ordinance was not reasonably related to promoting traffic safety and that community aesthetics was not a legitimate purpose for the exercise of the pohice power. In addition, the plaintiffs alleged that the ordinance was invalid because the police power inay not be used to totally exclude a lawful business that has not been held to be a public nuisance.

pensation for removal of billboards within 660 feet of a federal primary or interstate highway, and visible from such highway. $26 \mathrm{Cal}$. 3d at 878, $610 \mathrm{P} .2 \mathrm{~d}$ at $425,164 \mathrm{Cal}$. Rptr. at 528. This Note will not deal with this aspect of the case.

The court also rejected, with minimal discussion, the plaintiffs' claim of denial of equal protection with respect to those billboards for which no compensation was required by statute, the claim that the anortization period was inadequate, and the clain that the city council failed to comply with the Cahfornia Environmental Quality Act. The Note will not discuss these areas.

25. 26 Cal. 3d at 888-96, 610 P.2d at 430-36, 164 Cal. Rptr. at 533-39 (Clark, J., dissenting).

26. 26 Cal. $3 \mathrm{~d}$ at 855,610 P.2d at 409,164 Cal. Rptr. at 512.

27. Birkenfeld v. City of Berkeley, 17 Cal. 3d 129, 159, 550 P.2d 1001, 1023, 130 Cal. Rptr. 465,487 (1976).

28. See Ratkovich v. City of San Bruno, 245 Cal. App. 2d 870, 879, 54 Cal. Rptr. 333, 338 (1st Dist. 1966); Lees v. Bay Area Air Pollution Control Dist., 238 Cal. App. 2d 850, 857, 48 Cal. Rptr. 295, 299 (1st Dist. 1965); Note, City Wide Prohibition of Billboards: Police Power and the Freedom of Speech, 30 Hastings L.J. 1597, 1600 (1979).

29. 26 Cal. 3d at 858 n.6, 610 P.2d at 411 n.6, 164 Cal. Rptr. at 514 n.6. 


\section{A. The Relationship Between Billboards and Traffic Safety}

Although promoting traffic safety is accepted as a legitimate government purpose for exercising the police power, the relationship between billboards and traffic accidents is uncertain. It is possible that roadside signs distract drivers and that distracted drivers cause accidents. The existence of this relationship is a matter of continuing controversy. ${ }^{30}$ As one writer put it: "[n]o inatter what one's position on the sign and safety issue one can find the study to support it." ${ }^{31}$ For a court to find a regulation to be a vahd exercise of the police power, however, a relationship between the regulation and the government purpose need not be proven; it is sufficient that it not be manifestly unreasonable to conclude that such a relationship exists. ${ }^{32}$ Since at least some evidence can be found to support the existence of a relationship between billboards and traffic accidents, it is not unreasonable to conclude that banning billboards and signs will promote traffic safety. The Cahfornia Supreme Court was therefore correct in holding that the billboard ordmance was reasonably related to the purpose of promoting traffic safety. ${ }^{33}$

\section{B. Aesthetics as a Regulatory Consideration}

The problem of whether the police power may be exercised to further aesthetic considerations is somewhat more troublesome. An old Cahfornia precedent, Varney \& Green v. Williams, ${ }^{34}$ held unconstitutional an ordimance prohibiting all advertising billboards. In that case, the court stated that "it has never been held that [aesthetic] considerations alone will justify, as an exercise of the police power, a radical restriction of the right of an owner of property." 35 Since that case was decided, however, the scope of the police power has come to be unore liberally interpreted. An increasing number of jurisdictions ${ }^{36}$ accept Justice Douglas' view as set out in Berman v. Parker:

The concept of the public welfare is broad and inclusive. . . . The values it represents are spiritual as well as physical, aesthetic as well as

30. Id. at 859,610 P.2d at 412,164 Cal. Rptr. at 515 .

31. Dowds, Private Signs and Public Interests, in 1974 lnstitute on Planning, Zoning, and Eminent Doinain 231.

32. Ratkovich v. City of San Bruno, 245 Cal. App. 2d 870, 879, 54 Cal. Rptr. 333, 338 (Ist Dis. 1966).

33. But see John Donnelly \& Sons v. Campbell, 639 F.2d 6, 11 (1st Cir. 1980) (finding that the challenged sign law could not be supported on highway safety grounds because its scope and exceptions were not tailored toward the goal of safety, and because the evidence did not show that signs cause accidents).

34. 155 Cal. 318,100 P. 867 (1909).

35. Id. at 320,100 P. at 868 .

36. See Bufford, Beyond the Eye of the Beholder: A New Majority of Jurisdictions Authorize Aesthetic Regulation, 48 U. Mo. K.C. L. REv. 125, 166 (1980). 
monetary. It is within the power of the legislature to determine that the community should be beautiful as well as healthy, spacious as well as clean, well-balanced as well as carefully patrolled. ${ }^{37}$

In accordance with this type of reasoning, a number of courts have upheld sign and billboard bans on the basis of aesthetic considerations. ${ }^{38}$

Some courts, however, have been reluctant to accept this broad view of the police power. One reason for not recognizing the validity of exercising the police power for aesthetic purposes is that aestletic values can vary tremendously from person to person. ${ }^{39}$ Because there is little consistency in defining beauty, guidelines are difficult to articulate and might be applied arbitrarily.

Despite these criticisins, the broader view is preferable. Few people today would argue with Justice Douglas' statement that the general welfare includes aesthetic as well as monetary values. ${ }^{40}$ It is difficult to imagine the government now exercising powers such as zoning without reference to aesthetic considerations. ${ }^{41}$ Increased prosperity and awareness has led to a shift in public priorities away from purely economic concerns and toward environmental and "quality of life" concerns. In addition, mcreased government regulation in all fields has led to acceptance of the view that the government has the power to regulate to promote these new concerns. In short, the California Supreme

37. 348 U.S. 26, 33 (1954). Accord, City of Phoenix v. Fehlner, 90 Ariz. 13, 17, 363 P.2d 607, 609-10 (1961); Eldridge v. City of Palo Alto, 57 Cal. App. 3d 613, 630, 129 Cal. Rptr. 575, 585 (1st Dist. 1976) overruled on other grounds, Agins v. City of Tiburon, 24 Cal. 3d 266, 273, 598 P.2d 25 , 28, 157 Cal. Rptr. 372, 375 (1979). People v. Stover, 12 N.Y.2d 462, 467-68, 191 N.E.2d 272, 275, 240 N.Y.S.2d 734, 738 (1963); Oregon City v. Hartke, 240 Ore. 35, 47-48, 400 P.2d 255, 261-62 (1965). See Williams, Subjectivity, Expression, and Privacy: Problems of Aesthetic Regulation, 62 MnN. L. Rev. 1, 2 (1977).

38. Donnelly Advertising Corp. v. City of Baltimore, 279 Md. 660, 370 A.2d 1127 (1977); Cromwell v. Ferrier, 19 N.Y.2d 263, 225 N.E.2d 749, 279 N.Y.S.2d 22 (1967); Markham Advertising Co. v. State, 73 Wash. 2d 405, 439 P.2d 248 (1968), appeal dismissed, 393 U.S. 316 (1969).

39. See City of Passaic v. Paterson Bill Posting Co., 72 N.J.L. 285, 287, 62 A. 267, 268 (1905) (striking down sign law on grounds that nobody should be deprived of property because "his tastes are not those of his neighbors"); City of Youngstown v. Kahn Bros. Bldg. Co., 112 Ohio St. $654,661,148$ N.E. 842,844 (1925) ("the public view as to what is necessary for aesthetic progress greatly varies . . . . The world would be at a continual seesaw if aesthetic considerations were permitted to govern the use of the police power."); Note, City Wide Prohibition of Billboards: Police Power and the Freedom of Speech, 30 Hastings L.J. 1597, 1602 (1979). But see Williams, supra note 37, at 6-7 (arguing that lack of consensus is insufficient to invalidate legislation based on aesthetic judgments, and that in any event consensus often exists on aesthetic inatters); Note, Beyond the Eye of the Beholder: Aesthetics and Objectivity, 71 Mich. L. REv. 1438 (1973).

40. See Comment, Aesthetic Zoning, The Right to Travel, and Growth-Restrictive Ordinances: Construction Industry Association of Sonoma County v. City of Petaluma, 61 IowA L. REv. 602, 608-12 (1975) (documenting the imcreasing acceptance of aesthetics as part of the "general welfare"); Comment, Architectural Controls: Aesthetic Regulation of the Urban Environment, 6 URB. LAW. 622, 628-30 (1974).

41. See 26 Cal. $3 d$ at 862,610 P.2d at 414,164 Cal. Rptr. at 517. 
Court's holding that the police power may be exercised for aesthetic purposes is in accordance with the needs of a modern community, and the current conception of the public welfare. Since the police power should be considered in light of the needs and situation of the community, ${ }^{42}$ the court was correct in overruling Varney \& Green and with it the notion that improving community aesthetics is not a legitimate purpose for the exercise of the police power.

\section{Prohibition vs. Regulation}

Plaintiffs in Metromedia argued that the police power can never be used to completely prohibit a busmess not found to be a public nuisance. ${ }^{43}$ As the court recognized, however, distinctions between a regulation and a prohibition are largely semantic-every sign regulation prohibits certain types of signs, or signs in certain locations. In this case, for example, the city characterized the ordmance as a "regulation of advertising," while the plaimtiffs characterized it as a "prohibition of off-site advertising." 44 As the United States Supreme Court has observed, "every regulation necessarily speaks as a prohibition."45 It would therefore be foolish to follow a formalistic rnle based on the verbal distmction between "regulation" and "prohibition."

Instead, it would be reasonable to follow the general rnle that the exercise of the police power is justified when it has some rational relation to the protection of public health, morals, safety, or general welfare, and is not employed in an arbitrary, unreasonable, oppressive, or discriminatory way. ${ }^{46}$ It cannot be argued that a total prohibition is not rationally related to legitimate police power goals, ${ }^{47}$ or that it is unreasonable or oppressive, merely because it is a total prohibition; sucl arguments revert to conclusory verbal formulas again. The court therefore correctly held that a "total prohibition" is not in itself an abuse of the police power, and that on the facts of this case, no abuse of the police power had been shown..$^{48}$

42. See Euclid v. Ambler Realty Co., 272 U.S. 365, 388 (1926).

43. 26 Cal. 3d at 863, 610 P.2d at 414-15, 164 Cal. Rptr. at 517-18.

44. Id. at 864,610 P.2d at 416,164 Cal. Rptr. at 519 (emphasis added).

45. Goldblatt v. Hempstead, 369 U.S. 590, 592 (1962).

46. See notes 27-28 and accompanying text supra.

47. For discussion of the legitimacy of the goals on the San Diego ordinance and the reasonableness of their relationship to that ordinance, see text accompanying notes 30-42 supra.

48. As inentioned earlier, see note 24 supra, this Note does not deal with the adequacy of the amortization period for pre-existing signs. If this period were too short, of course, there would be a denial of due process. See $26 \mathrm{Cal}$. 3d at 882, 610 P.2d at 427, 164 Cal. Rptr. at 530. 
III

The First Amendment Issues

The California Supreme Court next dealt with whether the San Diego ordinance was a constitutionally valid time, place, and manner restriction on speech. ${ }^{49}$ In so doing, the court properly applied the well-established test for determining whether such a regulation is valid: courts will uphold restrictions on the time, place, and manner of speeclr "provided that they are justified witlout reference to the content of the regulated speech, that they serve a significant governmental interest, and that im so doing they leave open ample alternative channels for communication of the infornation."50 One must remeinber, liowever, that commercial speecli receives less constitutional protection than noncommercial speech. ${ }^{51}$ The Supreme Court has repeatedly recognized "the 'commonsense' distimction between speech proposing a commercial transaction, which occurs in an area traditionally subject to government regulation, and other varieties of speech."52 Therefore, the manner in which the test described above is applied depends on whether the restrictions affect commercial or noncommercial speecli. This part of the Note first exammes the types of speech affected by the ordinance, then evaluates the validity of the ordmance as applied to commercial speecli and to noncommercial speech.

\section{A. Types of Speech Covered by the Ordinance}

The first step im analyzing the first amendment issues in the case is to define the scope of those issues. Specifically, does this case mvolve regulation of commercial speech only, or of noncommercial speecli as well? The language of the ordinance does not speak in ternis of the type of speech, but prohibits all off-site "outdoor advertising display signs." 53 The scope of the first amendment issues thus depends on the definition of this phrase.

The definition adopted by the court, borrowed from a completely unrelated section of the state tax code, defines "outdoor advertising display sign" as "a rigidly assembled sign, display, or device pernanently

49. $26 \mathrm{Cal} .3 \mathrm{~d}$ at $867-71,610$ P.2d at 417-20, $164 \mathrm{Cal}$. Rptr. at 520-23. Since the court had held that the federal constitutional issue had been settled by the Supreme Court's dismissal of the appeal in Suffolk Outdoor Advertising Co. v. Hulse, 43 N.Y.2d 483, 373 N.E.2d 263, 402 N.Y.S.2d 368 (1977), appeal dismissed, 439 U.S. 808 (1978), the analysis of the validity of the ordinance was made under Cahfornia constitutional law. The court, however, relymg on masy federal cases, analyzed the the issue no differently than it would have under the Federal Constitution.

50. Virgmia Bd. of Pharnacy v. Virginia Consumer Council, 425 U.S. 748, 771 (1976).

51. Central Hudson Gas \& Elec. Corp. v. Pubhc Service Comm'n, 447 U.S. 557, 563 (1980).

52. Ohrahk v. Ohio State Bar Ass'n, 436 U.S. 447, 455-56 (1978); see Young v. American Mini Theaters, 427 U.S. 50 (1976).

53. 26 Cal. 3d at 856,610 P.2d at 410,164 Cal. Rptr. at 513. 
affixed to the ground or permanently attached to a building or other inherently permanent structure constituting, or used for the display of, a commercial or other advertisement to the public."54 The court's purpose in adopting this definition was to avoid construing the ordinance to apply to labor picket signs and small political or rehigious signs displayed im one's front yard, which it felt would raise serious constitutional problems. ${ }^{55}$ The court's definition, however, does not exclude noncommercial messages displayed on permanently fixed billboards, since it includes any billboard containing "a commercial or other advertisenent to the public." The court at one point recogmized that "relatively few noncomınercial advertisers" would be affected by the ordinance. ${ }^{56}$ But, despite adopting this definition, the court characterized the problem as one involving "commercial billboards,",57 and analyzed the issue almost completely in terms of commercial speech. ${ }^{58}$

The ordinance sliould, im fact, have been construed to cover all billboards, including those displaying noncommercial inessages, since it was clearly not drafted to apply only to billboards carrying commercial speech. The ordinary meaning ${ }^{59}$ of the general provisions of the ordmance, prohibiting off-site "outdoor advertising display signs," indicates that the ordinance should cover any type of sign, regardless of the nature of its message. ${ }^{60}$ In addition, the fact that the San Diego City Council thought it necessary to make explicit exceptions for temporary political cainpaign signs and rehgious synbols ${ }^{61}$ indicates that its members believed that the general provisions applied to signs carry-

54. CAL. Rev, \& TAX CODE $\S 18090.2$ (c)(3) (West Supp. 1980). The court admitted that this definition was not before the San Diego City Council when it adopted the billboard ordinance, but stated that adoption of the definition would "fulfill the city's purpose of banning permanent structures used predominantly for commercial advertising." 26 Cal. $3 \mathrm{~d}$ at 856 n.2, 610 P.2d at 410 n.2, 164 Cal. Rptr. at 513 n.2.

55. Id. at 856 n.2, 610 P.2d at 410 n.2, 164 Cal. Rptr. at 513 n.2.

56. Id. at 869, 610 P.2d at 418-19, 164 Cal. Rptr. at 521-22.

57. Id. at 866,610 P.2d at 416,164 Cal. Rptr. at 519 .

It is assumed that when the court used the phrase "commercial billboards," it meant billboards containing a cominercial message, since the court proceeded to analyze the case almost completely in terms of commercial speech. It is possible that the court intended "commercial billboards" to mean billboards that contain paid advertisements, regardless of the commercial or noncominercial contents of the advertisements. But speech does not become commercial speech merely because it is im the form of a paid advertisement. New York Times Co. v. Sullivan, 376 U.S. 254 (1964). Thus, construing the ordinance to apply to billboards that contam paid advertisements would not justify analyzing the constitutionality of the ordinance as a restriction only on commercial speech.

58. The analysis relies completely on precedents and reasoning from coinmercial speech cases.

59. A court must give language its ordinary meaning. Gilbert v. City of Los Angeles, $33 \mathrm{Cal}$. App. 3d 1082, 1087, 109 Cal. Rptr. 622, 626 (2d Dist. 1973). See CAL. Civ. Proc. Code $§ 1858$ (West 1955).

60. See text accompanying note 53 supra.

61. See note 17 and accompanying text supra. 
ing noncommercial speech. Moreover, since certain exceptions to the general provisions are explicitly listed, no exception exempting billboards carrying noncommercial speech should be imphed. ${ }^{62}$ Thus, the San Diego ordinance, as properly construed, applies to billboards carrying noncommercial as well as commercial speech.

Although the exceptions to the ordinance exempt some limited types of noncommercial speech, such as temporary political cainpaign signs, from the billboard ban, the ordinance would prevent much noncommercial speech from being communicated via billboards. The parties stipulated that "valuable commercial, political, and social information is communicated to the public through the use of outdoor advertising,"63 so it is evident that San Diego's billboards actually have carried noncommercial messages. Indeed, the dissenting opimion in Metromedia gives a number of examples of noncommercial messages found on San Diego billboards: protests agamst involveinent in the Umited Nations and Vietnam, protests agamst rismg taxes, condemnation of the assassmation of the Israeh athletes at the Munich Olympic Games, and support of the 55 mile-per-hour speed limit. ${ }^{64}$ Therefore, it is clear that the San Diego ordinance operates to ban some noncoinmercial speech as well as commercial speech.

The Califorma Supreme Court was thus wrong in analyzing the free speech problem solely in terms of commercial speech. The terms of the ordmance as written, and the court's own construction, show that the ordmance apphies to noncommercial speech as well. ${ }^{65}$ The issue properly before the court was the constitutionality of an ordimance affecting both commercial and noncommercial speech. ${ }^{66}$

\section{B. Constitutionality of the Ordinance as Applied to Commercial Speech}

The court gave the commercial speech problem full consideration.

62. See City of Coronado v. California Coastal Zone Conservation Comm'n, 69 Cal. App. 3d 570, 580, 138 Cal. Rptr. 241, 247 (1977).

63. 26 Cal. 3d at 857, 610 P.2d at 411, 164 Cal. Rptr. at 514 (Joint Stipulation No. 28).

64. Id. at $888-89,610$ P.2d at 431,164 Cal. Rptr. at 534.

65. The San Diego City Council, according to the court, intended the ordinance to apply to commercial billboards. $26 \mathrm{Cal}$. 3d at $856 \mathrm{n} .2,610$ P.2d at $410 \mathrm{n} .2,164 \mathrm{Cal}$. Rptr. at $513 \mathrm{n} .2$; see note 57 supra. But since the court's construction of the ordinance does not give it this effect, this intent is irrelevant to the analysis.

66. Since Metromedia suffered a direct economic injury due to the alleged constitutional violation, it had standing to raise the claim that the free speech rights of its customers were violated. See Burns v. State Compensation Insurance Fund, 265 Cal. App. 2d 98, 104-05, 71 Cal. Rptr. 326, 330 (1968); $c f$. Village of Arlington Heights v. Metropolitan Housing Dev. Corp., 429 U.S. 252, 261 (1977) (standing in federal courts). Since Metroinedia's custoiners apparently used the billboards for both noncommercial and commercial inessages, see note 63 and accompanying text supra, Metromedia can challenge the ordinance on both counts. 
In rejecting Metroinedia's first ainendment argument, the court drew support from a number of decisions of federal courts and courts of other states. Then, applying the three part test of validity for regulation of the time, place, and maimer of speech, ${ }^{67}$ the court found that the San Diego ordmance was content neutral, that it served a significant government interest, and that there were adequate alternative inethods of communication available.

\section{Precedent}

The California Supreme Court in Metromedia found that the United States Supreme Court had already passed on the first amendment challenges to billboard bans. ${ }^{68}$ The court based this conclusion on the Supreme Court's dismissal, for lack of a substantial federal question, of the appeal from the decision of the New York Court of Appeals in Suffolk Outdoor Advertising Co. v. Hulse ${ }^{69}$ In that case, the New York court had upheld a billboard prohibition enacted by the town of Southhampton. The California court held that the dismissal of the appeal by the Umited States Supreme Court must be treated as a decision on the merits, and that, therefore, the federal constitutional question was no longer open to dispute.

This conclusion, although appealing im its simphicity, ignores the complexity of the law in this area. The California court cited the Supreme Court decision in Hicks v. Miranda ${ }^{70}$ to support the proposition that a dismissal of appeal for lack of a substantial federal question is a decision on the inerits of the federal claim. This is certainly a proper reading of Hicks, which states that " "votes to . . . dismiss for want of a substantial federal question, it hardly needs comment, are votes on the merits of a case." "71 The Court im Hicks reasoned that when a case is within the Court's mandatory appellate jurisdiction, ${ }^{72}$ there is no discretion to refuse to decide the merits, and that even a summary disposition must therefore be a decision on the inerits.

Subsequent case law, lowever, has refined the rule expressed in Hicks. A dismissal for lack of a substantial federal question does not indicate the agreement of the Court with the opinion and reasoning of

67. See text accompanying note 50 supra.

68. Apparently the Supreme Court does not agree that it has fully considered the issues raised by billboard bans; it has decided to hear Metronedia's appeal from the decision of the California Supreme Court. $101 \mathrm{~S}$. Ct. 265 (1980) (noting probable jurisdiction).

69. 43 N.Y.2d 483, 373 N.E.2d 263, 402 N.Y.S.2d 368 (1977), appeal dismissed 439 U.S. 808 (1978).

70. 422 U.S. 332 (1975).

71. Id. at 344 (quoting Brennan, J., in Ohio ex rel. Eaton v. Price, 360 U.S. 246, 247 (1959)) However, the Hicks court warned that there inight be difficulty in determining "the reach and content of summary actions." Id. at 345 n.14.

72. See 28 U.S.C. $\$ 1257(2)$ (1976). 
the lower court; the inference is only that the Supreme Court agrees with the judgment. ${ }^{73}$ In addition, a summary dismissal decides only the issues specifically presented im the jurisdictional statement and necessary to the resolution of the case; it does not decide issues that "merely lurk in the record." "74

The jurisdictional statement of the appellant in Suffolk vigorously presented the commercial speech issue to the Supreme Court. ${ }^{75}$ It stated that "the issue of First Amendment protection of outdoor advertising is . . . open in this Court $m$ the sense that the Court has not ruled specifically on billboards since the constitutional protection of commercial speech becaine clear."76 The appellant argued that the commercial speech cases established that the town could not ban billboards solely because of their "predommantly commercial" nature since commercial speech is protected by the first annendment. The appellant's analysis concluded that the billboard ordinance was an impermissible restriction because it exceeded the limits on regulation of the time, place, and manner of speech. Since the appellant specifically raised the commercial speech issue, the Court's summary affirmance im Suffolk may be said to have decided that billboards carrying commercial speech inay be prohibited by local ordinance.

However, even tlrough the Court can be said to have decided the commercial speech issue by its summary affirmance, such a summary decision is of limited precedential value. The Court reserves the right to fully consider a question that has been the subject of a previous summary action, ${ }^{77}$ and to discard a rule "which a line of summary affirmances nay appear to have established."78 As the Court has said, a summary action has "considerably less precedential value than an opmion on the merits." " Given the weak precedential value of a sum-

73. Washington v. Confederated Bands and Tribes of the Yakima Indian Nation, 439 U.S. 463, 477 n.20 (1979); Mandel v. Bradley, 432 U.S. 173, 176 (1977).

74. Illinois Elections Bd. v. Socialist Workers Party, 440 U.S. 173, 182-83 (1979); Mandel v. Bradley, 432 U.S. 173, 176 (1977).

75. Jurisdictional Statement at 10-23, Suffolk Outdoor Advertising Co. v. Hulse, Docket No. 77-1670 (U.S., filed May 23, 1978).

76. Id. at 11 .

77. Washington v. Confederated Bands and Tribes of the Yakima Indian Nation, 439 U.S. 463,477 n.20 (1979).

78. Illinois Elections Bd. v. Socialist Workers Party, 440 U.S. 173, 181 (1979) (quoting concurring opinion of Burger, C.J., in Fusari v. Steinberg, 419 U.S. 379, 392 (1975)).

79. Illinois Elections Bd. v. Socialist Workers Party, 440 U.S. 173, 180-81 (1979); Washington v. Confederated Bands and Tribes of the Yakina Indian Nation, 439 U.S. 463, 477 n.20 (1979); Edelman v. Jordan, 415 U.S. 651, 670-71 (1974). See generally P. BATOR, P. MISHKIN, D. ShapiRo \& H. Wechsler, Hart \& WechSler's The Federal Courts and the Federal SysTEM 648-49 \& Supp. 160-64 (2d ed. 1973 \& Supp. 1981); Note, Summary Disposition of Supreme Court Appeals: The Significance of Limited Discretion and a Theory of Limited Precedent, 52 B.U. L. REv. 373, 404-23 (1972); Cominent, The Precedential Weight of a Dismissal by the Supreme Court for Want of a Substantial Federal Question: Some Implications of Hicks v. Miranda, 76 
mary action, the California Supreme Court was wrong to conclude that Suffolk conclusively settled the first amendment issue under the federal constitution.

In addition to Suffolk, the California Supreme Court relied on a number of state and lower federal court decisions upholding sign ordinances agamst first amendment challenges. ${ }^{80}$ These cases are distinguisliable from Metromedia. One group of cases ${ }^{81}$ dealt witl billboard laws passed in conformity with the federal Highway Beautification Act of $1965 .^{82}$ These statutes typically prohibit only billboards within 660 feet of certam highways, and do not apply to areas zoned for commercial and industrial use. The ordinance in another case cited by the court allowed billboards im areas zoned commercial, light manufacturing, and heavy manufacturing; sucli zones were found to be numerous and geographically distributed throughout the city. ${ }^{83}$ An additional case dealt with a ban on billboards only im a limited urban renewal area; billboards were allowed-and frequently used-im other parts of the city. ${ }^{84}$ In all of these cases the restrictions involved were significantly more limited than San Diego's virtually total prohibition. Because ample alternative channels of communication were available, these regulations were not as dangerous to first amendment imterests as the San Diego ordimance. Thus, these cases also provide little support for holding the San Diego ordimance constitutional.

The validity of the court's decision therefore rests heavily on its mdependent determination that the ordinance is a valid time, place, and manner regulation of speech. This requires that the ordimance be content neutral, ${ }^{85}$ that it serve a siguificant government interest, and that it leave open adequate alternative channels of communication. ${ }^{86}$

CoLum. L. REv. 508, 519-33 (1976); Note, The Precedential Effect of Summary Affirmances and Dismissals for Want of a Substantial Federal Question After Hicks v. Miranda and Mandel v. Bradley, 64 VA. L. REV. 117, 119-41 (1978).

80. $26 \mathrm{Cal} .3 \mathrm{~d}$ at 866,610 P.2d at 416-17, $164 \mathrm{Cal}$. Rptr. at 519-20.

81. Newman Signs, Inc. v. Hjelle, 268 N.W.2d 741 (N.D. 1978), appeal dismissed, 440 U.S. 901 (1979); Stuckey's Stores, Inc. v. O'Cheskey, 93 N.M. 312, 600 P.2d 258 (1979), appeal dismissed, 100 S. Ct. 2145 (1980); Ackerley Communications, Inc. v. City of Seattle, 92 Wash. 2d 905, 602 P.2d 1177 (1979), appeal dismissed, 101 S. Ct. 49 (1980); Markham Advertising Co. v. State, 73 Wash. 2d 405, 439 P.2d 248 (1968), appeal dismissed, 393 U.S. 316 (1969); State v. Lotze, 92 Wash. 2d 52, 593 P.2d 811, appeal dismissed, 444 U.S. 921 (1979).

82. 23 U.S.C. $\S 131$ (1976).

83. Lubbock Poster Co. v. City of Lubbock, 569 S.W.2d 935 (Tex. Civ. App. 1978).

84. Donnelly Advertising Corp. v. City of Baltimore, 279 Md. 660, 622-23, 370 A.2d 1127, 1129 (1977).

85. "Content neutral" is shorthand for "not justified with reference to the content of the speech." See text accoinpanying note 50 supra.

86. Id. 


\section{Content Neutrality}

In finding that the ordinance was content neutral, the court overlooked the effect of soine of the ordinance's exceptions. The ordinance does, in fact, discriminate between different types of cominercial speech based on their content. It does not restrict signs advertising products sold on the premises or offering the site for sale or rent ("on-site" signs). ${ }^{87}$ Whether a commercial sign is permitted under the ordinance depends on the inessage conveyed by the sign. For exainple, a storekeeper could have a sign on the side of his building advertising his store's products, but not one advertising a local bank. This is clearly regulation based exclusively on the content of the inessage. ${ }^{88}$

The on-site/off-site distinction, however, does not possess the vices that the content neutrahty rule is designed to prevent, because it does not discriminate against any particular inessage. The hist of permissible topics varies from billboard to billboard, depending on what products are inade or sold on the premises; any commercial message may appear soinewhere in the city so long as the advertised product is made or sold in San Diego. Therefore, although the prohibition of off-site signs is a content restriction, it does not impose the kind of systematic elimination of particular messagcs that the content neutrality rule is primarily intended to prevent.

Moreover, although the traditional rule against content-based restrictions on speech $^{89}$ strictly forbids discrimmation among various types of speech based on their content, a more relaxed standard should be applied when a content-based restriction on commercial speech is involved. The rule against content discrimination is derived from equal protection and first annendinent principles. ${ }^{90}$ When discrimination is between various types of commercial activity, however, traditional equal protcction principles indicate that a ligh degree of deference is due to the government; ${ }^{91}$ in economic regulation, the government may inake classifications where these have a rational relation to a legitimate government purpose. ${ }^{92}$ Discrimination between various types of speech of a commercial nature should, therefore, be allowed more readily than discrimination between various types of noncom-

87. 26 Cal. $3 d$ at 856 n.1, 610 P.2d at 410 n.1, 164 Cal. Rptr. at 513 n.1.

88. The on-site/off-site distinction is not merely a regulation of the place of speech. It does not put some places off limits for all public speech; rather, it discriminates between speakers based on the content of their messages.

89. See notes 118-19 and accompanymg text infra.

90. Chicago Pohice Dep't v. Mosley, 408 U.S. 92 (1972). See notes $120-22$ and accompanying text infra.

91. See Dandridge v. Williams, 397 U.S. 471 (1970); Williamson v. Lee Optical Co., 348 U.S. 483 (1955).

92. Williamson v. Lee Optical Co., 348 U.S. 483. 
mercial speech, since it takes place in an area traditionally subject to government regulation. ${ }^{93}$

In addition, the case law inandates that content-based restrictions should be more widely upheld when commercial speech is involved than when noncommercial speech is affected. ${ }^{94}$ The United States Supreme Court has upheld content-based restrictions on commercial speech enacted for a number of reasons: to protect the public from deceptive and misleading advertising; 95 to prevent fraud, undue imfluence, overreaching, and imtimidation; ${ }^{96}$ and to prevent the consummation of an illegal activity. ${ }^{97}$ On the other hand, regulation of the content of commercial speech has been held unconstitutional where the regulation was intended to prevent the free flow of information to the consumer, ${ }^{98}$ or to prevent a legal transaction from occurring. ${ }^{99}$ In general, restrictions on the content of commercial speech are upheld when the restriction is reasonably calculated to serve a substantial government interest, and is not intended to hamper the free flow of accurate information. ${ }^{100}$

Since San Diego's off-site billboard ban was imtended to improve community aesthetics and enhance traffic safety rather than to suppress any type of information, the key inquiry becomes whether the offsite/on-site distinction bears a reasonable relationship to the ordi-

93. Ohralik v. Ohio State Bar Ass'n, 436 U.S. 447, $455-56$ (1978); Central Hudson Gas \& Elec. Co. v. Public Serv. Comm'n, 447 U.S. 557, 562 (1980).

94. But see Redish, The First Amendment in the Marketplace: Commercial Speech and the Values of Free Expression, 39 GEO. WASH. L. REv. 429 (1971) (contending that commercial speech can embody free speech values and should therefore be fully protected under the first amendment). See also Baker, Commercial Speech: A Problem in the Theory of Freedom, 62 lowA L. REv. 1 (1976) (arguing that commercial speech deserves no protection); Karst, Equality as a Central Principle in the First Amendment, 43 U. CHI. L. REv. 20 (1975) (arguing that any two-tier approach is unsupportable).

95. See Friedman v. Rogers, 440 U.S. 1 (1979) (prohibition of the use of trade names by optometrists).

96. See Ohralik v. Ohio State Bar Ass'n, 436 U.S. 412 (1978) (prohibition of in-pcrson solicitation by attorneys).

97. See Pittsburgh Press Co. v. Pittsburgh Comm'n on Human Relations, 413 U.S. 376 (1973) (newspaper prohibited from publishing gender-designated want ads due to illcgality of sex discrimination). Although this case was decided before the Court announced first amendment protection for commercial speech, the Court lias since reaffirmed the holding. See, e.g., Central Hudson Gas \& Elec. Co. v. Public Serv. Comın'n, 447 U.S. 557 (1980).

98. See Virginia Bd. of Plarmacy v. Virginia Consumcr Council, 425 U.S. 748 (1976) (pharinacists prohibited from advertising prices); Bates v. State Bar of Arizona, 433 U.S. 350 (1977) (attorneys prohibited froin advertising prices).

99. See Linmark Associates, Inc. v. Township of Willingboro, 431 U.S. 85 (1977) (prohibition of "for sale" signs).

100. Cf. Central Hudson Gas \& Elec. Co. v. Public Serv. Comm'n, 447 U.S. 557, 566 (1980) (Speech protected by the first amendment may be regulated if the regulation directly advances a substantial governmental interest, and is not more extensive than is necessary to serve that intcrest. This test is a departure from prior analysis, and seems to be an aberration. Application to this case would not change the result of the analysis.). 
nance's goals. The distinction is reasonably related to these goals in a special sense: no blanket prohibition of on-site advertising would be constitutional. ${ }^{101}$ This is due to the fact that there is no real alternative to on-site advertising. ${ }^{102}$ The purpose of on-site advertising is identification of the business; the targeted audience consists of those who are in the immediate vicinity. In other words, both the message and the audience are site-specific; there is no effective way except by using signs to get the inessage to the audience. Simce the first amendment prohibits regulation of the tinie, place, and inanner of speech when there are no alternative inethods of communication, the use of on-site signs could not be prohibited. The ordinance's goals of aesthetics and traffic safety could thus not be constitutionally served without an exemption for onsite signs. Since the ordinance's content restriction is reasonably calculated to serve the government goals and is not intended to suppress the free flow of information, it is vahd. ${ }^{103}$

\section{Government Interest and Alternative Methods of Communication}

Since the San Diego ordinance's content-based distinctions are justified, the validity of the ordinance depends on whether it serves a significant government interest, and whether there remain ample alternative methods of communication. ${ }^{104}$ These factors interact: a greater government interest will make less effective alternatives acceptable. In addition, the same government imterest may justify acceptance of less effective alternatives for commercial speech than for noncominercial speech. This is true for two reasons: first, our society is not as concerned about preserving commercial speech as noncoinmercial speech because we place a lesser value on the former; and second, commercial speech is less fragile than noncommercial speech, because the profit motive will always provide a powerful incentive to speak. ${ }^{105}$ Compared with the reduced first amendinent imterest in protecting commercial speech, San Diego's interest in enhancing community aesthetics and increasing traffic safety is significant. The regulation should, therefore, be valid even if no equally effective alternative channels are open, so long as any feasible alternative channels exist, even if these channels are less effective or inore costly.

101. Cf. Linmark Associates, Inc. v. Township of Willingboro, 431 U.S. 85 (1977) (holding unconstitutional a prohibition of on-site "for sale" signs).

102. See State v. Lotze, 92 Wash. 2d 52, 59, 593 P.2d 811, 814-15, appeal dismissed, 444 U.S. 921 (1979).

103. Although such a rationale would not justify regulating noncommercial speech, content restrictions on coinmercial speech are not judged as strictly. See text accompanying notes 89-100 supra.

104. See text accompanying note 50 supra.

105. See Bates v. State Bar of Arizona, 433 U.S. 350 (1977). 
As the court correctly held, feasible alternatives to billboards and signs do exist for most commercial advertisers. Newspapers, magazmes, radio, and television are all possible methods for reaching a comparable audience. Of course, those advertisers for whom these methods are not feasible alternatives may challenge the constitutionality of the ordinance as applied to them. ${ }^{106}$ But the fact that a law may be unconstitutionally applied to some commercial speakers does not mean that the ordinance is invahd as apphed to all commercial speakers. ${ }^{107}$ The court was therefore correct in holding that sufficient alternatives existed for commercial speakers to satisfy the constitutional requirement.

In combimation with the satisfaction of the content neutrality requirement, the existence of ample alternative channels of communication relative to the importance of the government's interests means that the San Diego ordinance is a valid time, place, and manner restriction as applied to commercial speech. To this extent, then, the California Supreme Court's loolding uplioldimg the ordinance against first amendment challenges is correct, despite the court's reliance on cases of limited precedential value. The constitutionality of the ordimance as applied to noncommercial speech, lowever, was largely neglected by the court and presents different problems.

\section{Constitutionality of the Ordinance as Applied to Noncommercial Speech}

The California Supreme Court ended its analysis of the first amendment problem in Metromedia with its finding that the infringeinent on commercial speech was perinissible. However, since the ordinance also posed noncommercial speecli problems, ${ }^{108}$ the California court's analysis was incomplete: the court should have considered the constitutionality of the infringement on noncommercial speech. This section of the Note first examines the applicability of the precedent cited by the court to the issue of the validity of the ordinance as apphed to noncommercial speech. It then analyzes the constitutionality of the ordinance as a time, place, and manner restriction of noncommercial speech.

\section{Precedent}

Suffolk Outdoor Advertising Co. v. Hulse may be weak precedent

106. 26 Cal. 3d at 869 n.14, 610 P.2d at 419 n.14, 164 Cal. Rptr. at 522 n.14.

107. See Bates v. State Bar of Arizona, 433 U.S. 350 (1977) (holding that such an ovcrbrcadth attack is not appropriate when commercial speech is involved).

108. See notes 53-66 and accompanying text supra. 
for upholding billboard bans affecting commercial speech, ${ }^{109}$ but it is even weaker precedent for upholding billboard bans affecting noncommercial speech. The issue of whether the Southampton ordinance could be constitutionally applied to noncommercial speech was not specifically raised by the appellant in the jurisdictional statement filed in the Supreme Court, and so remained inerely "lurk[ing] $\mathrm{m}$ the record." 110 Despite scattered references to noncommercial speech, the appellant in Suffolk treated the problem as one of commercial speech, ${ }^{111}$ and challenged it for violating the constitutional protection given cominercial speech. The Supreine Court thus did not specifically face the question of whether billboards carrying noncommercial speecl may also be prohibited by such an ordinance, and therefore can not be said to have decided that question by its summary dismissal. The majority in Metromedia, therefore, erred im merely citing Suffolk to dispose of the issue. ${ }^{112}$

Similarly, besides being distinguishable on other grounds, ${ }^{113}$ many of the state and lower federal court decisions relied on by the Califorma Supreine Court mvolved restrictions that affected only commercial inessages. ${ }^{114}$ These cases, like Suffolk, are not directly applicable to the problem of determining the validity of San Diego's ordinance as applied to noncommercial speech. Therefore, the ordinance's validity depends on whether, as applied to noncommercial speech, it is content neutral, serves a significant government interest, and leaves open adequate alternative channels of communication. ${ }^{115}$

\section{Content Neutrality}

Although the ordinance's general provisions prohibit all off-site

109. See notes 68-79 and accompanying text supra.

110. See note 74 and accompanying text supra.

111. See note 58 and accompanying text supra.

112. See notes 68-69 and accompanying text supra.

113. See notes 80-84 and accompanying text supra.

114. Howard v. State Dep't of Highways, 478 F.2d 581, 585 (10th Cir. 1973) ("only commercial advertising signs and directional signs are involved"); John Donnelly \& Sons v. Outdoor Advertising Bd., 369 Mass. 206, 226, 339 N.E.2d 709, 721 (1970) (administrative board found that signs "contain purely commercial copy"); Snffolk Outdoor Advertising Co. v. Hulse, 43 N.Y.2d $483,489,373$ N.E.2d 263, 265, 402 N.Y.S.2d 368, 370 (1977) ("State inay regulate time, place, and Inanner of commercial speech"- court did not consider possible application of law to noncommercial speecli). This is also true of one case in which the court construed a sign law rather liberally in order to exempt noncommercial messages. See John Donnelly \& Sons v. Mallar, 453 F. Supp. 1272 (D. Me. 1978) ("noncommercial inessages sucl as those conveyed by political, civic, and clraritable signs, are specifically exeinpted"). This decision was reversed in John Donnelly \& Sons v. Campbell, 639 F.2d 6 (1st Cir. 1980). The conrt of appeals stated that the statute could be applied lawfully to commercial speecl, but that the statute also reached noncommercial speech, not all of which was "specifically exempted." The court lield that the statute therefore violated the first amendment. Id. at 15-16.

115. See note 50 and accoinpanying text supra. 
billboards regardless of content, the exceptions differentiate between permissible and impermissible signs solely on the basis on content. For example, the ordinance permits "temporary political campaign signs ... which are erected or maintained for no longer than 90 days and which are removed within 10 days after the election to which they pertain."116 The ordinance also permits "religious symbols, holiday decorations, and other such signs." 117 Unlike the exemption for on-site signs, these exceptions systematically discriminate agamst inessages having a certain content; whether the ordinance excludes a given sign depends solely on the sign's content. The San Diego sign law is thus a classic example of a content-based restriction on speech. It permits the display of inessages that the city council considers valuable or useful while banning the display of other messages. The strict rule against content regulation ${ }^{118}$ is designed to guard against just this type of discrimmation. ${ }^{119}$

This case is similar to Chicago Police Department v. Mosley. ${ }^{120}$ Mosley involved a ban on picketing near schools, except labor picketing. The Court found such a discriminatory rule to be unconstitutional:

[A]bove all else, the First Amendment means that government has no power to restrict expression because of its message, its ideas, its subject matter, or its content. . . .

Necessarily, then, under the Equal Protection Clause, not to mention the First Amendment itself, government may not grant the use of a forum to people whose views it finds acceptable, but deny use to those wishing to express less favored or more controversial views. And it may not select which issues are worth discussing or debating in public facilities. There is an "equahty of status in the field of ideas" and government inust afford all points of view an equal opportunity to be heard. ${ }^{121}$

Like the prohibition in Mosley, San Diego's billboard ban has a discriminatory impact, allowing the forum to be used only for speecli on certain designated subjects, and closing the foruin to all other speech.

116. San Diego Ordinance No. 12189 (New Series) (Oct. 19, 1977).

117. San Diego Ordinance No. 10795 (New Series) (Mar. 14, 1972).

118. The government may regulate speech based on the content of the speech only in certain limited cases such as hbel, Gertz v. Robert Welch, Inc., 418 U.S. 323 (1974); "fighting words," Chaplinsky v. New Hampshire, 315 U.S. 568 (1942); obscenity, Miller v. California, 413 U.S. 15 (1973); and speech intended, and likely, to incite imminent lawless action, Brandenburg v. Ohio, 395 U.S. 444 (1969).

119. See Lehman v. City of Shaker Heights, 418 U.S. 298, 316 (1974) (Brennan, J., dissenting) ("That the discrimination is anong entire classes of ideas, rather than among points of view within a particular class, does not render it any less odious. Subject matter or content censorship in any form is forbidden.").

120. 408 U.S. 92 (1972).

121. Id. at $95-96$ (citations oinitted). 
Mosley thus supports the proposition that the San Diego ordinance is unconstitutional. ${ }^{122}$

The decision in Lehman v. City of Shaker Heights, ${ }^{123}$ holding that a city selling commercial advertising space in buses is not required to accept political advertisements, would seem to indicate that, despite the Mosley rule, a city may discriminate based on content of speech. This case, however, relied on facts present in neither Mosley nor $\mathrm{Me}$ tromedia. In Lehman, the court justified its decision by finding that buses are not a "First Amendment forum," that the city had an interest in avoiding abuse or the appearance of favoritism in allocating space among political candidates, and that bus passengers, as a captive audience, have privacy rights. ${ }^{124}$ In Metromedia, a traditional first a1nendment foruin is involved: the streets, froin which billboards are generally viewed. ${ }^{125}$ Since the city is not the seller of advertising space, there is no problem of abuse or favoritism. Finally, although viewers of billboards are in one sense a "captive audience," 126 an uninvited encounter with a billboard is relatively fleeting, while a bus passenger is a "captive" for a sustained period of time. In short, the facts in $M e$ tromedia are unlike those in Lehman, and similar to those in Mosley. Supreme Court precedent thus supports the view that the San Diego ordinance should have been held unconstitutional due to its discriminatory treatment of different types of speech. ${ }^{127}$

The California Supreme Court, however, ignored Mosley and concluded that the ordinance did "not seek to suppress the content of the advertiser's message." 128 The court compared this case to other cases in which speecl1 was regulated through prohibition of specific messages, such as price hists. ${ }^{129}$ Since the San Diego sign law did not aim at sup-

122. See Note, Freedom of Expression in the Land Use Planning Context: Preserving the Barrier of Presumptive Validity, 28 U. FLA. L. REv. 954, 960 (1976) ("Mosley thus represents a significant limitation on the police power that seemingly can be applied to invalidate a zoning ordinance that discriminates as to content of expression."). See also Cox v. Louisiana, 379 U.S. 536 (1965) (Cox I) (statute applied in a discriminatory way to restrict speecli lield unconstitutional). But see Young v. American Mini Tlieaters, Inc., 427 U.S. 50 (1976) (uplrolding an "anti-skid row" zoning ordinance which discriminated against adult theaters and bookstores based on the content of speecli). Young is distinguislsable in that it involved a density requirement, not a complete prohibition.

123. 419 U.S. 298 (1974).

124. Id. at 302-04.

125. See Kalven, The Concept of the Public Forum: Cox v. Louisiana, 1965 SuP. CT. REv. 1.

126. See 418 U.S. at 302 (dicta).

127. See Karst, supra note 94. Karst argues that "the principle of equal liberty lies at the heart of the first amendinent's protections against government regulation of the content of speech." Id. at 21. Karst also argues that to the extent Lehman is inconsistent with Mosley, "the plurality opinion [in Lehman] . . . fails the test of craftsmanship as well as the test of good sense, offering instead an idea whose time has come and gone." Id. at 35.

128. $26 \mathrm{Cal} .3 \mathrm{~d}$ at 868,610 P.2d at 418,164 Cal. Rptr. at 521.

129. See Virginia Bd. of Pliarmacy v. Virginia Consumer Council, 425 U.S. 748 (1976). 
pressing any particular message, the court concluded that the ordinance was content neutral. ${ }^{130}$ In so concluding, the court neglected the fact that the ordinance classifies speech on some topics as permissible, and speech on other topics as forbidden. ${ }^{131}$ Although the ordinance does not suppress any particular message, it is definitely not content neutral. The court was therefore wrong in holding that the ordinance did not violate the requirement of content neutrality.

\section{Government Interest and Alternative Methods of Communication}

Even if the San Diego ordinance were strictly even-handed, and banned all off-site billboards regardless of the message displayed, it would still probably not be constitutionally valid. To be a valid time, place, and manner regulation, a regulation must serve a significant government interest and leave open acceptable alternative methods of commumication. ${ }^{132}$ While merely feasible alternatives may be sufficient to restrict commercial speech, reasonably interchangeable alternatives generally must exist to restrict noncommercial speech. ${ }^{133}$ Although alternatives to billboards and signs, such as newspapers and radio, do exist, there is strong evidence that these alternative inethods are not as cost-effective. ${ }^{134}$ Billboards also have the unique advantage of focussing the message on a specific geographic region. Moreover, the parties in Metromedia stipulated that "[m]any businesses and politicians and other persons rely upon outdoor advertising because other forms of advertising are insufficient, mappropriate, and prohibitively expensive." 135 This stipulation seems to dictate the conclusion that no alternative channel of equal effectiveness is available to many persons precluded from using billboards.

Given the lack of any reasonably interchangeable alternatives, the government can justify the restriction on noncommercial speech only by showing that it serves a very strong interest. The government inter-

130. 26 Cal. 3d at 868,610 P.2d at 418,164 Cal. Rptr. at 521.

131. It is true that alteruative methods of speech are available for the speech which cannot appear on billboards. But the availability of alternatives does not, in itself, justify regulation. Schneider v. State, 308 U.S. 147, 163 (1939). Furthermore, the availability of alternatives for prohibited speech does not mitigate the evil of discrimmatory treatment of differcnt types of speech.

132. See text accompanying note 50 supra.

133. See text accompanying note 105 supra.

134. In 1976, the average costs of reaching 1000 people by various media were as follows: for outdoor advertising (signs and billboards), 41 cents; for a 30-second commercial on network radio, $\$ 1.39$; for a 30 -second cominercial on daytime local radio, \$1.94; for prime-time network television, \$2.93; for a one-page four-color ad in one of the top 50 magazines, $\$ 6.77$; for a thousand-line newspaper ad (less than half a page), \$10.17. 12 Media Decisions 109, 112 (Aug. 1977) (cited in Jurisdictional Statement at 15, Suffolk Outdoor Advertising Co. v. Hulse, Docket No. 77-1670 (U.S., filed May 23, 1978)); see John Donnelly \& Sons v. Cainpbell, 639 F.2d 6, 16 (1st Cir. 1980). 135. 26 Cal. 3d at 857, 610 P.2d at 411 , 164 Cal. Rptr. at 514 (Joint Stipulation No. 28). 
est in enhancing community aesthetics is substantial, but not sufficiently compelling to justify suppressing speech for which there may exist no equally effective alternatives. ${ }^{136}$ The Supreme Court has noted that unwilling viewers may avoid "bombardment of their sensibilities simply by averting their eyes."137 Speech should not be suppressed on the grounds that it takes an unsightly form. ${ }^{138}$ The government interest in increasing traffic safety is also substantial, but the San Diego ordinance is not narrowly tailored to serve that interest. The ordinance does not characterize signs according to their dangerousness to traffic safety; in fact, the ordinance seems to completely disregard this factor. $^{139}$ This lack of fit significantly weakens the government's traffic safety interest in the restriction, especially in a first amendment case. ${ }^{140}$ Therefore, neither the interest in enhancing community aesthetics nor the interest in increasing traffic safety justifies the restriction on noncommercial speech imposed by the San Diego ordinance. ${ }^{141}$

The Califormia Supreme Court disposed of these problems simply by stating that the government interest was sigmificant, and that a ban on billboards leaves open adequate alternatives for communication. ${ }^{142}$

136. This conclusion is bolstered by decisions of several federal courts of appeal. In Baldwin v. Redwood City, 540 F.2d 1360 (9th Cir. 1976), the Ninth Circuit held that severe restrictions on political campaign signs were invalid, after balancing the government's interests against the first amendment interests, taking into account the lack of true alternatives to signs. The First Circuit also has struck down a sign prohibition on first amendment grounds. In John Donnelly \& Sons v. Campbell, 639 F.2d 6 (lst Cir. 1980), the court held that the sign law inposed excessive restrictions on noncommercial speech. The court relied on the fact that outdoor advertising is far less expensive than alternative methods. Id. at 16. See also Stone, Fora Americana: Speech in Public Places, 1974 SUP. CT. REv. 233, 256-58 (arguing that a prohibition of signs expressing views on "public issues" is unconstitutional due to the lack of equivalent alternative methods of speech).

137. Cohen v. California, 403 U.S. 15, 21 (1971); Erznoznik v. City of Jacksonville, 422 U.S. 205, 211 (1975); $c f$. Kovacs v. Cooper, 336 U.S. 77 (1979) (discussed at note 141 infra).

138. See Note, Architecture, Aesthetic Zoning, and the First Amendment, 28 STAN. L. REv. 179 (1975). The author argues that architectural design is a form of expression protected by the first amendment, and therefore that regulation of design for aesthetic reasons is impermissible. In the case of billboards, which involve pure speech instead of some vague concept of self-expression, this conclusion applies a fortiori.

139. For example, it would seein that on-site signs are more likely to cause traffic accidents than off-site signs, since on-site signs might cause the driver to make sudden, erratic movements in traffic in order to avoid passing by the busimess or shop which he has noticed too late. Yet the ordinance permits on-site signs, while prohibiting off-site signs.

140. See Baldwin v. Redwood City, 540 F.2d 1360 (9th Cir. 1976); John Donnelly \& Sons v. Campbell, 639 F.2d 6 (1st Cir. 1980); $c f$. Shelton v. Tucker, 364 U.S. 479, 488 (1960) (court should consider "less drastic means for achieving the same basic purpose").

141. This conclusion does not conflict with the reasoning of Kovacs v. Cooper, 336 U.S. 77 (1949). In that case, the Court upheld a ban on sound trucks emitting loud and raucous noises. Although a ban on sound trucks resembles a ban on billboards in form, the cases are distinguishable. First, sound trucks impose a much greater burden on individual privacy; an unwilling hearer cannot avoid sound, and a sound truck can even invadc the home. Second, the ban in Kovacs was narrowly tailored to the purpose at hand, since it applied only to loud and raucous noises.

142. 26 Cal. $3 d$ at $868-69,610$ P.2d at 418,164 Cal. Rptr. at 521 . 
The court acknowledged that "an occasional advertiser" might not have adequate alternatives to signs, but the court left this issue to be decided on a case-by-case "as applied" basis. ${ }^{143}$ As the dissent pointed out, this conclusion "ignores both the joint stipulation of facts . . . and traditional First Amendment overbreadth analysis."144

Under overbreadth analysis, it need not be shown that the ordinance is unconstitutional as applied in every situation; if it is unconstitutional in any application, the ordinance is completely invalid because it is overbroad. Overbreadth analysis is appropriate when constitutionally protected speakers might be deterred froin exercising first amendment rights by the threat posed by the overbroad statute. ${ }^{145}$ Since it is the very existence, not the application, of the statute that deters the exercise of first amendment rights, enforceinent of the statute is coinpletely forbidden, even against unprotected speakers. ${ }^{146}$

Although overbreadth analysis would not be appropriate if the San Diego ordimance applied only to noncommercial speakers, ${ }^{147}$ it is appropriate in this case because the ordinance may be unconstitutional as applied to soine noncommercial speakers. Consider, for example, the local anti-abortion activist who has no equally effective alternative method of speech, and to whoin the ordinance could thus not be constitutionally applied. Not knowing this in advance, the activist might refrain from posting signs and buying billboard space in order to avoid a lawsuit and the loss of his time and noney. This is precisely the danger against which overbreadtl analysis is directed. Therefore, the San Diego ordinance should be struck down on its face as overbroad.

The analysis of the San Diego ordinance as applied to noncommercial speech thus reveals that the ordimance is not a permissible time, place, and manner regulation for two reasons. First, the ordinance discriminates between different types of speech based on their content with no compelling reason. Such censorship is forbidden under the Mosley rule by equal protection and first amendment principles. Second, given the lack of equally effective alternatives available to those who would communicate noncommercial messages by signs, the stated government objectives of improved appearance and traffic safety are insufficient to justify the total prohibition of signs and billboards. The

143. Id. at 869 n. 14,610 P.2d at 419 n.14, 164 Cal. Rptr. at 522 n.14.

144. Id. at 896 n.3, 610 P.2d at 436 n.3, 164 Cal. Rptr. at 539 n.3.

The stipulation directly contradicts the court, stating that many people have no adequate alternatives to outdoor advertising. See note 63 and accompanying text supra.

145. See Coates v. City of Cincinnati, 402 U.S. 611, 618-19 (1971) (White, J., dissenting). See generally Note, The First Amendment Overbreadth Doctrine, 83 HARv. L. REv. 844 (1970).

146. See Broadrick v. Oklahoma, 413 U.S. 601 (1973).

147. Bates v. State Bar of Arizona, 433 U.S. 350,380 (1977). 
California court thus erred in upholding the San Diego ordinance. ${ }^{148}$

\section{CONCLUSION}

The Cahifornia Supreme Court in Metromedia properly recognized that under modern law and in response to the needs of a modern community, the government's interest in aesthetics justifies exercising the police power. The court was also correct in holding that the San Diego sign ordmance did not interfere with first amendment protection of commercial speech. However, the court was too quick to analyze the San Diego ordinance as if it only raised commercial speech problems. To the contrary, the ordimance unconstitutionally impinges on noncommercial speech. The ordmance is unconstitutional because it impermissibly discriminates between different types of speech based on their content, and because of the lack of good alternatives for the use of billboards and signs. In treating the issue as one of commercial speech, the court neglected the noncommercial speech problems. Courts facing similar issues in the future should take note, and give noncommercial speech the full first amendment protection that it deserves. $\dagger$

Terry T. Johnson*

148. This error may be partly due to the fact that the court improperly dealt with the ordinance as affecting only commercial speech, to which lesser protection attaches. The court did not clearly explain the importance of this fact to its decision.

$\dagger$ Editors' Note: When this Note was written, the Metromedia appeal was pending before the United States Supreme Court. Since the Note was in its final stages of publication when the Court's decision was announced, 49 U.S.L.W. 4925 (June 30, 1981), it was not possible to revise it. The Court's four-Justice plurality, in an opinion by Justice White, struck down San Diego's billboard ordinance as unconstitutional on its face due to its impermissible restrictions on noncommercial speech, an analysis sitnilar to that proposed in this Note. Id. at 4931-32. Justices Brennan and Blackmun concurred in the judgment, finding that the city had failed to establish adequate traffic safety and aesthetic justification. Id. at 4935-36 (Brennan, J., concurring). The concurring justices also concluded that a city could totally ban billboards if it showed the ban would further a "sufficiently substantial governmental interest," $i d$. at 4935 (Brennan, J., concurring), but they rejected the plurality's view that an ordinance banning all commercial billboards but allowing noncommercial billboards would be constitutional. Id. at 4937-38 (Brennan, J., concurring). Chief Justice Burger and Justices Stevens aud Rehnquist would have upheld San Diego's ordinance. Id. at 4939 (Burger, C.J., dissenting), 4942 (Rehnquist, J., dissenting) and 4943 (Stevens, J., dissenting).

* A.B. 1978, Stanford University; J.D. 1981, Boalt Hall Sclıool of Law, University of California, Berkeley. 